\title{
Impact of Material Serum Screening in Early Prenatal Diagnosis and Management of Congenital Anomalies
}

\begin{abstract}
CRISTINA-CRENGUTA ALBU ${ }^{*}$, SUZANA ELENA CILIEVICI ${ }^{2}$, DINU-FLORIN ALBU ${ }^{3}$, STEFAN-DIMITRIE ALBU ${ }^{4}$, ANCA PATRASCU5 ALEXANDRU MARIAN GOGANAU 6

IUniversity of Medicine and Pharmacy Carol Davila, Department of Genetics, 37 Dionisie Lupu Str., 020021, Bucharest, Romania ZUniversity of Medicine and Pharmacy Carol Davila, Department of Microbiology, 37 Dionisie Lupu Str., 020021, Bucharest, Romania

${ }^{3}$ University of Medicine and Pharmacy Carol Davila, Department of Obstetrics and Gynecology, 37 Dionisie Lupu Str., 020021, Bucharest, Romania

4University of Medicine and Pharmacy Carol Davila, Faculty of Dental Medicine, 37 Dionisie Lupu Str., 020021, Bucharest, Romania

5University of Medicine and Pharmacy of Craiova, Department of Obstetrics and Gynecology, 2 Petru Rares Str., 200349, Craiova, Romania

${ }^{6}$ University of Medicine and Pharmacy of Craiova, Department of General Surgery, 2 Petru Rares Str., 200349, Craiova,

Romania

It was performed a case-control study, that included totally 187 pregnant women hospitalized in ObstetricalGynecology Department of Prof. Dr. Panait Sarbu Hospital, Bucharest, Romania. The selection criteria for case sample were: age over 30 years, history of malformative risk, clinical exam that emphasised malformations and ultrasound examination that suspicioned embrio-fetal morphological abnormalities. We determined the serum levels of alpha fetoprotein (AFP), human chorionic gonadotropin (hCG) and unconjugated estriol (UE3), by immunoenzymometry. As statistical analysis we determined the estimated median value. For each of the three parametres, the final curve was compared with the value obtained by spectrophotometry. The study revealed the predictive value of correlated use of these three parameters, together with ultrasound examination and cytogenetic investigations, in order to early prenatal diagnosis of congenital fetal anomalies.
\end{abstract}

Keywords: maternal serum screening (MSS), alpha fetoprotein (AFP), human chorionic gonadotropin (hCG), unconjugated estriol (uE3), ultrasound examination

The prevention and early diagnosis of genetic diseases and congenital malformations can be facilitated through prenatal screening of pregnant women facing high risk [1]. The prenatal diagnosis is indicated in the following situations:

-maternal age over 35 years [2];

-couples in which one member is affected by a genetic disorder or birth defect [3];

-couples who have a child with mental retardation or malformation $[4,5]$;

-genetic malformations as a result of family history;

-spontaneous miscarriages in early pregnancy [6 - 8]; -consanguineous couples [9];

-genitors that belong to an isolated religion, ethnic group, geographical environment [10].

The prenatal diagnostic methods which are currently used are ultrasound examination, serum al pha fetoprotein and human chorionic gonadotropin determinations, unconjugated estriol determination, amniocentesis and chorionic villus sampling. [11 - 14]. The essential condition to develop genetic counseling is the accurate diagnosis [15].

This study, represents the systematic investigation of a group of pregnant women with an increased risk of giving birth to an abnormal child.

The study aims to demonstrate the predictive value of maternal serum screening in the early detection of malformed fetuses pregnancies.

The purpose of the study is to demonstrate the effectiveness of the method and implement it while following the pregnancy.

\section{Experimental part}

The 187 pregnant women were divided into two groups: a case group, containing 18 pregnant women, and a second grup, the observer group, containing 169 pregnant women.

The case group, containing 18 pregnant women hospitalized in the Prof. Dr. Panait Sarbu Obstetrics and Gynecology Hospital, Bucharest, Romania, were selected based on age, medical history, clinical examination and ultrasound examination results. These were subject to MSS by determining the concentration of AFP, hCG and uE3, by immunoenzymometry and spectrophotometry. The study period was 5 months.

The selection criteria, were:

-age - 30 years;

-history- the high risk of malformation pregnant women were considered the women who, regardless of age, had previously malformed fetuses pregnancies, or those whose families were recorded as having had genetic malformations;

-clinical examination - the presence of defects and/or genetic abnormalities;

-ultrasound examinations of pregnancy-routine standard ultrasound examination and additional ultrasound examinations, performed by an expert in maternal and fetal medicine. 
The serum to be analyzed was collected from the vein of pregnant women using aseptic techniques and observing universal precautions.

Determination of alpha-fetoprotein (AFP)

To determine the AFP concentration we used the Human Alpha-fetoprotein, AFP ELISA Kit.

Method of determining AFP:

$-50 \mu \mathrm{L}$ standard serum, control serum and determined serum were pipetted into the appropriate wells,

-over this was added $100 \mu \mathrm{L}$ of buffer solution and left at room temperature for $20 \mathrm{~min}$,

-washed with distilled water and then it is removed,

$-150 \mu \mathrm{L}$ of anti-AFP antibody conjugated with peroxidase is added to each, was incubated for $20 \mathrm{~min}$ at room temperature, then washed with distilled water;

-100 $\mu \mathrm{L}$ of tetramethylbenzidine solution and hydrogen peroxide is added and incubated for $15 \mathrm{~min}$ at room temperature,

the wells,

-pipette $100 \mu \mathrm{L} 0.3 \mathrm{M}$ solution of sulfuric acid $\left(\mathrm{H}_{2} \mathrm{SO}_{4}\right)$ in

-the extinction value was read at $450 \mathrm{~nm}$.

After determining the value extinction a standard curve was performed to which the extinction obtained for each serum is measured against.

\section{Determination of chorionic gonadotropin ( $h C G$ )}

Determination kit has 96 wells containing sheep anti hCG antibodies and mouse monoclonal antibodies specific for total hCG and $\beta$-hCG conjugated with peroxidase. For better precision two sets of measurements were used.

Method of determining hCG:

-pipette $50 \mu \mathrm{L}$ standard serum, control serum and determined serum in nearing wells,

-mixing the sera with antibodies by softly moving the plate for $30 \mathrm{~s}$,

-add $100 \mu \mathrm{L}$ buffer solution,

-stir for $10 \mathrm{~s}$ and allow to incubate for $60 \mathrm{~min}$ at room temperature,

-wash 5 times with distilled water which is then removed,

-to each well $150 \mu \mathrm{L}$ of peroxidase-conjugated antibodies solution is added, gently stir for $5 \mathrm{~s}$, incubate at room temperature for $30 \mathrm{~min}$, then wash with distilled water,

-tetramethylbenzidine-based solution is added it is stirred for $5 \mathrm{~s}$, -after 15 min of incubation at room temperature in a dark space, the reaction was stopped by adding $50 \mu \mathrm{L}$ per well,

-after $30 \mathrm{~min}$ the result of the extinction was read at 450 $\mathrm{nm}$

\section{Determination of unconjugated estriol (uE3)}

We used DRG Estriol test - immunoenzymometry method for the in vitro determination of unconjugated estriol in the maternal serum.

Method of determining uE3:

-pipette $10 \mu \mathrm{L}$ of standard estriol standard, control serum and determined serum into the appropriate wells,

-each well was added 100 $\mu \mathrm{L}$ of peroxidase-conjugated estriol and it was incubated at room temperature for 60 min,

-repeatedly wash with washing solution,

-after pipetting $100 \mu \mathrm{L}$ of substrate solution, it was incubated for $30 \mathrm{~min}$ at room temperature,

-the coloring was done by adding $100 \mu \mathrm{L}$ of stop agent,

-the spectrophotometric results was reading at wavelength of $490-500 \mathrm{~nm}$.

We used the determination of the estimated median value for each of the three determined parameters. The curve was compared with the value obtained by spectrophotometric determination.

\section{Results and discussions}

Analysis of the results allowed highlighting some interesting aspects in terms of the possibility of antenatal diagnosis, compared to the rest of 169 pregnant women at the same time for whom the same criteria were followed, but the MSS was not performed (table 1, fig. 1).

Alpha-fetoprotein (AFP) is a plasma protein produced by the embryonic yolk sac and the fetal liver, encoded by the AFP gene on chromosome 4q25 [16].

The determination of AFP concentration in maternal blood allows early diagnosis of fetal abnormalities [17]. Thus, low levels of AFP were associated with the presence of chromosome abnormalities, spontaneous abortion, preterm birth, fetal death, increased macrosomia, and elevated AFP levels have been associated with malformations such as spina bifida, neural tube defects, gastroschisis, polycystic kidney, liver necrosis, microsomes [18 - 20].

Human chorionic gonadotropin (hCG) is a pregnancy-

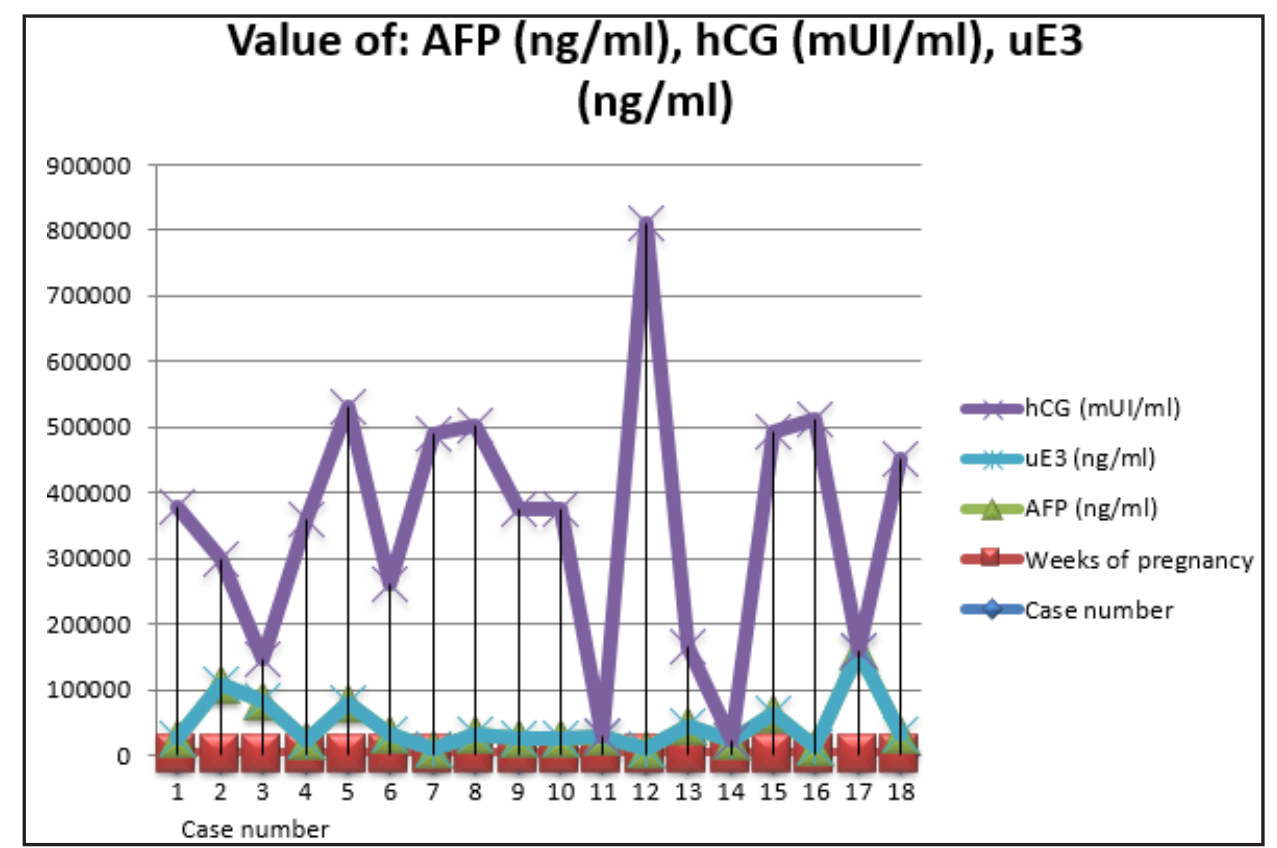

Fig.1. Value of AFP, hCG and $\mathrm{UE} 3$ 
specific hormone that regulates placental development and is produced by trophoblast cells from the time of embryo implantation onwards [21, 22].

The determination of $\mathrm{hCG}$, produced exclusively during pregnancy also allows the interpretation of the presence of abnormal pregnancies. High hCG values appear in multiple pregnancy, molar pregnancy, Rh isoimmunization, hydatidiform mole or choriocarcinoma. Low levels of $h C G$ in pregnancy suggests poor placental function, as found in miscarriage, ectopic pregnancy, fetal death [23 - 25].

Determination uE3 may indicate a series of fetal distress. Thus, undetectably low UE3 has been associated with: anencephaly, fetal death, congenital adrenal hypoplasia, Congenital Hypopituitarism, Smith-Lemli-Opitz Syndrome, and placental aromatase deficiency [26, 27]. High uE3 has not been associated with adverse perinatal outcomes [25].

Considering these observations as well as the application of MSS (AFP, hCG and UE3) in predicting risk for Down syndrome and other congenital anomalies, we started to use in the Clinic of Obstetrics and Gynecology of the Prof. Dr. PanaitSarbu Hospital in Bucharest the serial ultrasound test associated with dosages of AFP, hCG and uE3 [28]. When maternal serum screening is performed for the usual clinical indication , abnormal analyte results can be utilized for the identification of pregnancies at risk and to direct their clinical management [25].

From the data we obtained from the analysis performed on 18 pregnant women, selected on the basis of the previously mentioned criteria, we found that the AFP values, with two exceptions, were within normal range by age of pregnancy, with a minimum of $9200 \mathrm{ng} / \mathrm{mL}$ and a maximum of $160197 \mathrm{ng} / \mathrm{mL}$ (table 1, fig. 2).

The average value of the concentration of hCG was $42.002 \mathrm{ng} / \mathrm{mL}$. The standard deviation of $+/-39834.13$ shows a great dispersion of the concentration values. The two exceptions were represented by:

\begin{tabular}{|c|c|c|c|c|}
\hline $\begin{array}{c}\text { Case } \\
\text { number }\end{array}$ & $\begin{array}{l}\text { Weeks of } \\
\text { pregnancy }\end{array}$ & $\begin{array}{c}\text { AFP } \\
(\mathrm{ng} / \mathrm{ml})\end{array}$ & $\begin{array}{c}\mathrm{hCG} \\
(\mathrm{mUV} / \mathrm{ml})\end{array}$ & $\begin{array}{c}\text { nEB3 } \\
(\mathrm{ng} / \mathrm{ml})\end{array}$ \\
\hline$T$ & 19 & 25480 & 354043 & 7.187 \\
\hline 2 & 22 & 109439 & 190020 & 4.824 \\
\hline 3 & 18 & 81720 & 62952 & 7.81 \\
\hline 4 & 14 & 20679 & 339026 & 5.20 \\
\hline 5 & 18 & 80589 & 450000 & 3.624 \\
\hline 6 & 19 & 30470 & 229573 & 10.20 \\
\hline 7 & 14 & 10829 & 480000 & 1.500 \\
\hline 8 & 14 & 31655 & 472000 & 3.409 \\
\hline 9 & 17 & 24853 & 350200 & 4.242 \\
\hline 10 & 20 & 26016 & 350000 & 590 \\
\hline 11 & 14 & 28485 & $>500000$ & 2.899 \\
\hline 12 & 12 & 9200 & 800000 & 1.580 \\
\hline 13 & 22 & 43102 & 122989 & 21.12 \\
\hline 14 & 16 & 22522 & $>550000$ & 7.195 \\
\hline 15 & 24 & 61910 & 430000 & 18.96 \\
\hline 16 & 18 & 12250 & 500000 & 20.25 \\
\hline 17 & 31 & 160197 & $>550000$ & 12.22 \\
\hline 18 & 16 & 30640 & 420000 & 0.795 \\
\hline
\end{tabular}

Table 1

THE VALUE OF AFP, HCG AND $\mu E 3$

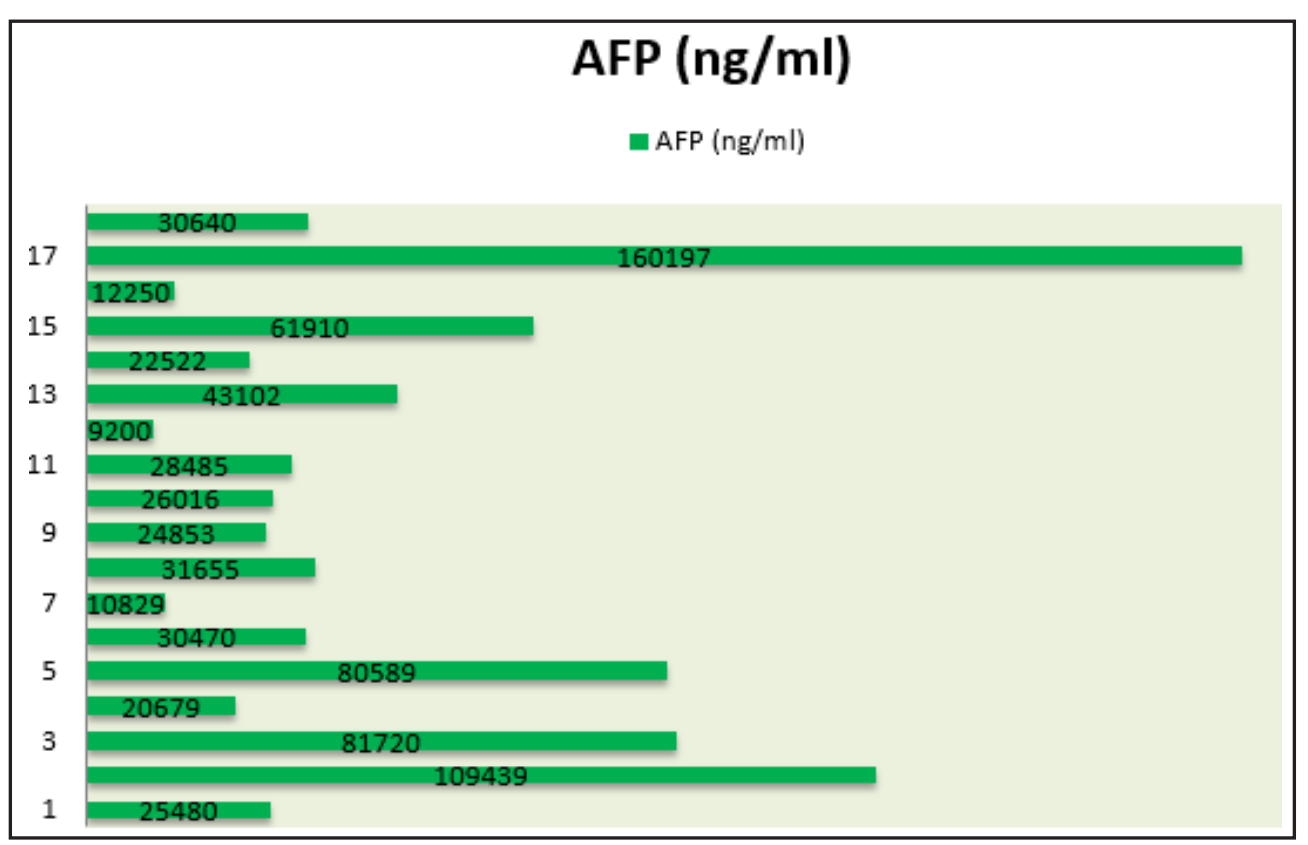

Fig. 2. Value of AFP (ng/mL) 
Case no. 2: pregnancy of 22 week, in which there were high levels of both AFP and hCG. This pregnancy aborted at the request of the patient.

Case no. 17: pregnancy of 31 week, with AFP growth over limit, associated with a significant increase in hCG > $550000 \mathrm{UI} / \mathrm{mL}$, uE3 falling within appropriate range considering pregnancy age, but at the lower limit. The newborn did not show malformations.

The highest value of hCG was $800000 \mathrm{mUI} / \mathrm{mL}$, while the lowest was $62952 \mathrm{mUI} / \mathrm{mL}$; The average concentration of hCG was $392266.83 \mathrm{mUl} / \mathrm{mL} \pm 173973.10$ (table 1, fig. 3).

Unconjugated estriol concentrations (uE3) ranged from $0.795 \mathrm{ng} / \mathrm{mL}$ and $21.120 \mathrm{ng} / \mathrm{mL}$, with a medium value of $7.72 \mathrm{ng} / \mathrm{mL} \pm 6.43$ (table 1, fig. 4).

Determining the correlation coefficients led to the following results:

$-h C G-u E 3 \quad r=-0.26$

$$
-0.65<R<0.23(p=0.05)
$$

-AFP - UE3 $r=-0.18$

$$
-0.32<R<0.59(p=0.0)
$$

-AFP - hCG $r=-0.22$ $-0.62<R<0.28(p=0.05)$

where: $r=$ the coefficient of correlation, $R=$ range of inclusion, $p=$ statistical risk (95\%).

The results of this maternal serum screening test (MSS) show a reverse relationship ( $r$ is negative) between hCG and UE3 levels, as confirmed by the birth of a child with hydrocephalus (Case no. 13). In this case, the investigations conducted at 22 weeks of pregnancy, showed the following results: AFP $=43.102 \mathrm{ng} / \mathrm{mL}$ (normal level), $\mathrm{hCG}=122989 \mathrm{mUI} / \mathrm{mL}$ (low level) and $\mathrm{UE3}=21.12$ $\mathrm{ng} / \mathrm{mL}$ (level increased a lot over the normal level).

In the Case no. 18, at a 16 weeks pregnancy, the variation of the concentrations were in reverse: AFP $=30.640 \mathrm{ng} /$ $\mathrm{mL}$ (normal level), $\mathrm{hCG}=420000 \mathrm{mUL} / \mathrm{mL}$ (much increased level) and uE3 $=0.795 \mathrm{ng} / \mathrm{mL}$ (low level). In this case, the pregnancy evolved normally.

There were two cases (Case no. 4 and Case no. 18) where $\mathrm{uE} 3$ and $\mathrm{hCG}$ values were increased:

In the Case no. 4, a pregnancy of 14 weeks, the serum determinations were: AFP $=20.679 \mathrm{ng} / \mathrm{mL}$ (normal level), $\mathrm{hCG}=339026 \mathrm{mUl} / \mathrm{mL}$ (high level) and $\mathrm{uE3}=5.2 \mathrm{ng} / \mathrm{mL}$ (much increased level). This pregnancy evolved normally to the birth of a healthy child.

In the Case no. 18, a pregnancy of 18 weeks, mother aged 36 years, the serum determinations were: AFP = $12.250 \mathrm{ng} / \mathrm{mL}$ (normal), $\mathrm{hCG}=500000 \mathrm{mUI} / \mathrm{mL}$ (much increased level), and uE3 $=20.25 \mathrm{ng} / \mathrm{mL}$ (much increased level). In this case the pregnancy was aborted at the request of the patient.

Subsequently, the MSS estimate at the malformation risk group allowed antenatal prognosis both of pregnancies
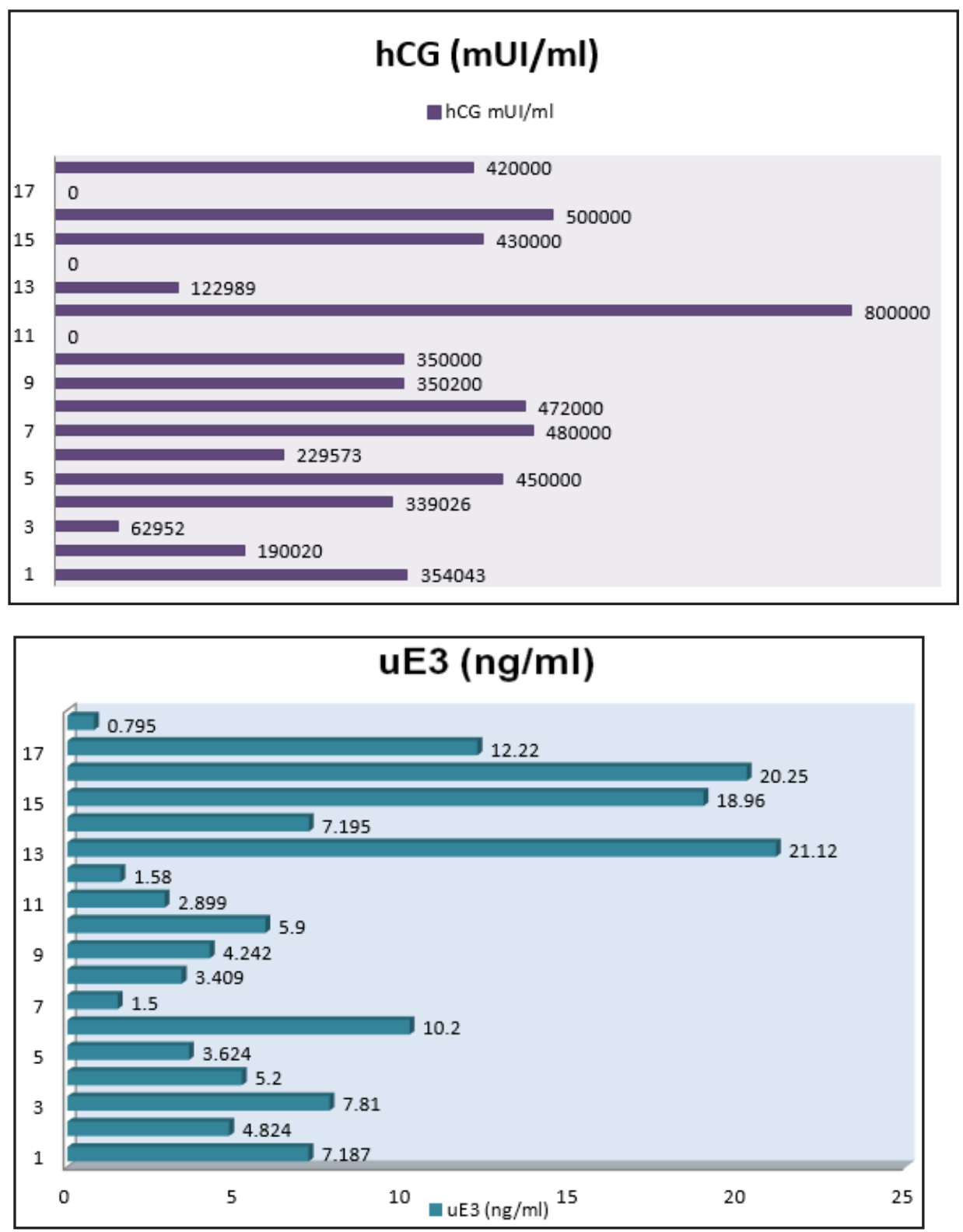

REV.CHIM.(Bucharest) $70 \bullet$ No. 5 • 2019
Fig. 3. Value of $\mathrm{hCG}(\mathrm{mUl} / \mathrm{mL})$

Fig. 4. Value of $u E 3(n g / m L)$ 
with normal fetuses, and those with malformed fetuses who were anatomical pathologically confirmed.

\section{Conclusions}

Maternal serum screening test is useful in the early prenatal detection of abnormal offspring. Therefore, MSS test is considered as a valuable method in prenatal diagnosis.

However, this method becomes of unquestionable value when combined with standard ultrasound exploration for the first trimester of pregnancy and second trimester of pregnancy.

The addition, cytogenetic examination, after amniocentesis, in case one or both of the previous tests indicate suspicion of a malformation, makes the triple test (ultrasound examination, MSS and cytogenetic investigation) to have a performance over $97-98 \%$ in prenatal diagnosis.

Our results, combined with those in the specialized literature , recommend the use of MSS test as a method of prenatal diagnosis.

If abnormalities of the concentration of AFP, hCG and uE3 occur, to avoid misinterpretation, the other two tests: ultrasound examination and cytogenetic exam are necessary, for a correct prenatal diagnostics and genetic counseling. In these cases the suspicion of genetic abnormalities, especially Down syndrome, is confirmed at a rate of $97-98 \%$.

In conclusion, MSS test constitutes a highly valuable method for prenatal diagnosis of genetic abnormalities and needs to be carried out by all pregnant women and especially those with genetic risk.

\section{Reference}

1.WIEACKER, P., STEINHARD, J. Dtsch Arztebl Int. 107, no 48, 2010, p. 857

2.GODINO, L., POMPILII, E., D'ANNA, F., ET AL. EurJ Hum Genet. 24, no 3,2015, p. 857

3.SHAPIRA, S.K., DOLAN, S. Matern Child Health J. 10, Suppl. 1, 2006, p. 143.

4.FINLEY, W.H., FINLEY, S.C. South Med J. 69, no 11, 1976, p. 1486 5.DAVE, U., SHETTY, D. J Obstet Gynaecol India. 64, no 1, 2013, p. 27 6.SCOTT, F., PETERS, H., BOOGERT, T., ROBERTSON, R., ANDERSON, J., MCLENNAN, A., KESBY, G., EDELMAN, D. Aust N Z J Obstet Gynaecol. 42, no 1, 2010, p. 55

7.CHOI, T.Y., LEE, H.M., PARK, W.K., JEONG, S.Y., MOON, H.S. Obstet Gynecol Sci. 57, no 6, 2014, p. 518

8.COHEN-OVERBEEK, T.E., HOP, W.C., DEN OUDEN, M., PIJ PERS, L., JAHODA, MG., WLADIMIROFF, J.W. Lancet. 336, no 8706, 1990, p. 27
9.NOURI, N., NOURI, N., TIRGAR, S., ET AL.J Med Ethics Hist Med. 10, no 12,2017, p. 1

10.FELLER, L., BALLYRAM, R., MEYEROV, R., LEMMER, J ., AYO-YUSUF, O.A. S. Afr. dent. j. 69, no 6, 2014, p. 272

11.ALBU, D., ALBU, C., ONCESCU, A. Ultrasound Obstet Gynecol, 42, Suppl. 1, 2013, p. 135. DOI:10.1002/uog.12990

12.ONCESCU, A., ALBU, D., ALBU, C. Ultrasound Obstet Gynecol, $\mathbf{4 2}$, Suppl. 1, 2013, p. 149. DOI:10.1002/uog.13039

13.ALBU, D.F., ALBU, C.C., ALBU, S.D., DUMITRESCU, M. Int J Med Res Rev. 107, no 3, 2015, p. 118

14.YARON, Y., CHERRY, M., KRAMER, R.L., O'BRIEN, J.E., HALLAK, M., JOHNSON, M.P., EVANS, M.I. Am J Obstet Gynecol. 181, no 4, 1999, p. 968

15.EL-HAZMI, M.A. Ann Saudi Med. 24, no 2, 2004, p. 84

16.ADIGUN, 0.0., BHIMJ I, S.S. Alpha Fetoprotein (AFP, Maternal Serum Alpha Fetoprotein, MSAFP). StatPearls Publishing, Treasure Island (FL), 2018Jan-.

17.CUCKLE, H.J Clin Med. 3, no 2, 2014, p. 504. DOI:10.3390/jcm3020504 18.ALBU, D. F., ALBU, C. , SEVERIN, E., TOMA, A. Ultrasound Obstet Gynecol, 26, no 4, 2005, p. 378. DOI:10.1002/uog.2245

19.SEPPALA, M., RUOSLAHTI, E. American Journal of Obstetrics and Gynecology, 115, no 1, 1973, p. 48

20.KRAUSE, T.G., CHRISTENS, P., WOHLFAHRT, J., LEI, U., WESTERGAARD, T., NORGAARD-PEDERSEN, B., ET AL. Obstet Gynecol. 97, no 2, 2001, p. 277

21.COLE, L.A. Reprod Biol Endocrinol. 8, 2010, p. 102. DOI:10.1186/ 1477-7827-8-102

22.BARJAKTAROVIC, M., KOREVAAR, TI., JADDOE, V.W., ET AL. Eur J Epidemiol. 32, no 2, 2016, p. 135

23.KOREVAAR, T.I., STEEGERS, E.A., DE RIJ KE, Y.B., ET AL. Eur J Epidemiol. 30, no 9, 2015, p. 1057

24.ESKANDAR, M.A., AL-SHAHRANI, M., SHAAMASH, A., EL-EMAIN, M., AL-AHMAD, M., PAYODON, J Clin Med Res. 3, no 1, 2011, p. 30

25.GAGNON, A., WILSON, R.D. Society Of Obstetricians And Gynaecologists Of Canada Genetics Committee. J Obstet Gynaecol Can. 30, no 10, 2008, p. 918. DOI: 10.1016/S1701-2163(16)32973-5.

26.MARSHALL, I., UGRASBUL, F., MANGINELLO, F., WAJ NRAJ CH, M.P., SHACKLETON, C. H. L., New, M. I., Vogiatzi, M. V. The Journal of Clinical Endocrinology \& Metabolism. 88, no 9, 2003, p. 4144.

27.SUMMERS, A.M., LANGLOIS, S., WYATT, P., WILSON, R.D., SOGC GENETICS COMMITTEE, CCMG PRENATAL DIAGNOSIS COMMITTEE, SOGC DIAGNOSTIC IMAGING COMMITTEE. J Obstet Gynaecol Can. 29, no 2, 2007, p. 146

28.ALBU, D.F., ALBU, C.C., ALBU, S.D. Int J Med Res Rev. 3, no 1, 2015, p. 117. DOI:10.17511/ijmrr.2015.101.022.

Manuscript received: 20.12 .2018 